city-manager plan under this most interesting experiment in representative government.

George W. Knox, commissioner at Niagara Falls, contributed a most interesting letter, making the point that the city-manager plan would be a most dangerous tool in the hands of a political machine, if the people of the community had no more public spirit than to prevent such a state of affairs, and that the success of this form depends upon a wide awake interested electorate. This is, of course, absolutely true, and it has been pointed out time and again that there is no royal road to good government, and its advocates must be prepared to fight for it, or they will have bad government under any plan.

\title{
THE ORGANIZATION OF A MUNICIPAL HEALTH DEPARTMENT ${ }^{1}$
}

\author{
BY M. N. BAKER ${ }^{2}$ \\ New York City
}

$I^{\mathrm{F}}$

F YOU are going in for an old-fashioned scheme with a mayor and a city council, with more or less overlapping powers, and a whole bunch of boards and commissions, each pretty much independent of the other and of the mayor and council as well, than I should suggest that you have a board of health of five members appointed by the mayor and not subject to confirmation by the city council or anybody else. I would suggest that such a board be given absolute powers within its field, except as regards expenditures. Possibly it might be provided that the board of health should be given some stated sum per capita per year for health purposes, but even this would seem to be questionable. In any event, the board, in common with all other city departments, should be rigidly required to submit a true budget every year which would comprise an estimate of its needs for the ensuing year alongside its actual appropriation for the current year and its actual expenditures for three to five previous years, all these to be itemized in accordance with a classification which would show the relation of the expenditures to the objects to be achieved. That is, the classification should be functional and should be most carefully designed to show what of the expenditures really had a relation to public health and what had not. I really do not think that such matters should be gone into in a city charter for each department, but that they should be covered in a general way for every department of the city.

${ }^{1}$ In response to an inquiry by the secretary of the Akron charter commission, Mr. Baker wrote a letter which so concisely stated the situation that the editor believes it would be of help to others interested in charter revision, and so it is reproduced herewith.

${ }^{2}$ Associate editor, Engineering News-Record; chairman, executive committee, National Municipal League. 
If in place of the old and haphazard scheme of city government you adopt the commission plan, then perforce the health work of the city must fall into some one of the various five so-called departments, so that the really responsible head will have health to look after in common with a lot of other things.

If you adopt the commission-manager plan, then you would simply have a single-headed health department under a man named health officer, presumably, though the name does not particularly matter, except to bring it in line with common practice, which is to use the term health officer.

Under the old commission plan, of course, all health ordinances would be enacted by the commission. The same would also be true under the commission-manager plan. If you had the old mixed system of government, with council, mayor and various boards, then, as I think it must be clear from what I have already written under that head, the board of health, and not the city council, should have all legislative power.

There must be a health officer or some equivalent under any of the three plans that $I$ have mentioned. These should in any case be vested with absolutely all executive powers-except, of course, that this is impracticable or out of harmony with the straight commission plan and should not be attempted under that plan.

Whatever you do, I sincerely hope you will limit the health department to strictly health protective work. That is, do not load it up with plumbing, street cleaning, garbage disposal, and a variety of other things that have little or no direct relation to the public health. Plumbing should go to the building department. The other things mentioned should be in the engineering department.

You raise a question regarding housing. This is so largely an economic matter, with various ramifications, that unless your conditions are exceptional, I should strongly advise keeping it entirely outside the health department. A health bureau and a housing bureau might both come within a larger department. This would naturally follow under the straight commission plan, and of course might be practised under either of the two.

If your charter finally provides for a board of health, by all means do not make it compulsory to have the board composed entirely of physicians or of any other professional or industrial class. The ideal board of five members might well be composed of two physicians, one sanitary engineer (or, if a sanitary engineer is not available, then of a sanitary chemist or sanitary biologist if either of those could be got), one lawyer and one business man. I do not feel sure that any such specification should be laid down in the city charter, especially one for a city no larger than Akron.

It is very important that the charter should not restrict the choice of a 
health officer to the medical profession and that it should distinctly provide (although that should be covered in some general provision relating to all executive officials) that non-residents may be engaged. The charter should provide that the health officer should be chosen with a view to getting a man whose education and training fit him for his work. It might say that the health officer must be a physician, a sanitary engineer or some other professional man whose education and experience particularly fit him for the position.

If Akron were a larger city, I might advise that the charter should be so framed that the health officer should be chosen primarily for his executive ability, but in a place no larger than yours the health officer will doubtless have to do things himself which will require specific training for his immediate tasks; that is, he will not be able to pick out specialists who will bring their special knowledge and training to merely carry out the policies decided by the health officer.

If you should decide upon the straight commission plan of government, then you will be up against it so far as any assurance that the department head under whom health matters fall will have any fitness whatever for his work in that field-or, as far as that goes, in any field requiring technical knowledge. Saying this is equivalent to saying that I hope you will not adopt the straight commission plan. That plan means electing executive officers and that in turn means failure of municipal government sooner or later-in spots if not all over.

I do not see how I can advantageously refer you to any literature that will help you very much in this matter, unless you or somebody for you is going to devote two or three years' time to making a study of all the branches of municipal government; or unless you are going to single out the health features of the charter for more particular study than is given to the others.

You doutbless have or will get six or ten of the best books dealing with municipal government and municipal charters in general. This I should think would be as far as you would be able to go. I could make up a list for you, but doubtless that is quite unnecessary as very likely you already have the books in hand or have taken steps to get them.

Permit me to suggest that, if you have not already done so, you talk over this whole matter with Mr. H. S. Morse, your new director of public service. As you doubtless know, he was connected with the bureau of municipal research at Cincinnati and with the bureau of governmental research at Detroit, and before that had practical experience in the engineering department of the city of Cincinnati. 